\title{
Pengaruh Problem Based Learning Terhadap Kemampuan Pemecahan Masalah Matematika di Kelas IV SD Ypk Lahairoy Yensawai
}

\author{
$\operatorname{Alman}^{1} \&$ Wanda Nely Intim Purwanty ${ }^{2}$ \\ Prodi PGSD, Universitas Pendidikan Muhammadiyah Sorong, Indonesia \\ ${ }^{\bowtie}$ E-mail: almankuntara87@gmail.com
}

\begin{abstract}
Abstrak
Penelitian ini bertujuan untuk mengetahui pengaruh problem based learning terhadap kemampuan pemecahan masalah matematika siswa kelas IV SD YPK Lahairoy Yensawai tahun ajaran 2020/2021. Jenis penelitian yang digunakan adalah penelitian kuantitatif dengan desain penelitian pretest-postest control design group. Sampel penelitian ini menggunakan random sampling, yaitu diundi 9 siswa untuk kelas eksprimen dan 8 siswa untuk kelas control. Uji validitas menggunakan uji ahli atau expert judgement dimana peneliti melibatkan dosen validator matematika dan guru kelas. Hasil uji reliabilitas soal pretest dan posttest kemampuan memecahkan masalah matematika berbasis soal cerita yang diujikan diatas 0,6 Alpha Croanbach's yaitu 0,500 atau 50\% untuk nilai pretest dan nilai posttest nya adalah 0,957 atau 95\%. Hasil uji normalitas data dengan Kolmogrov-Smirnov bahwa data variable berdistribusi normal karena nilai Asymp.Sig.(2-tailed) pada hasil pretest 0,464 dan 0,139 pada hasil posttest $\geq 0,05$ sebesar 1,74 (thitung > ttabel). maka dapat disimpulkan bahwa Ha diterima dan $\mathrm{H} 0$ ditolak yang berarti hipotesis penelitian terjawab karena dapat hasil yang signifikan terhadap kemampuan memecahkan masalah matematika siswa dengan menggunakan pembelajaran Problem Based Learning berpengaruh terhadap kemampuan pemecahan masalah matematika berbasis soal cerita.
\end{abstract}

Kata Kunci: Problem Based Learning; Kemampuan Pemecahkan Masalah; Matematika.

\begin{abstract}
This study aims to determine the effect of problem based learning on the mathematical problem solving abilities of fourth grade students of SD YPK Lahairoy Yensawai for the academic year 2020/2021. The type of research used is quantitative research with a pretest-posttest control design group. The sample of this study used random sampling, namely 9 students were drawn for the experimental class and 8 students for the control class. The validity test uses an expert test or expert judgment in which the researcher involves a mathematics validator lecturer and class teacher. The results of the reliability test of the pretest and posttest of the ability to solve math problems based on story questions tested above 0.6 Alpha Croanbach's is 0.500 or $50 \%$ for the pretest value and the posttest value is 0.957 or $95 \%$. The results of the data normality test by Kolmogrov-Smirnov that the data variables are normally distributed because the value of Asymp.Sig.(2-tailed) in the pretest result is 0.464 and 0.139 in the posttest result $\geq 0.05$ is 1.74 (tcount $>$ ttable). it can be concluded that Ha is accepted and $\mathrm{HO}$ is rejected, which means the research hypothesis is answered because it can produce significant results on students' mathematical problem solving skills using Problem Based Learning and affect story-based mathematical problem solving abilities.
\end{abstract}

Keywords: Problem Based Learning; Problem Solving Ability; Mathematis. 


\section{PENDAHULUAN}

Matematika merupakan salah satu mata pelajaran wajib di Sekolah Dasar (SD). Materi matematika di Sekolah Dasar (SD) yang mencakup aritmatika, geometri dan aljabar, sederhananya adalah rangkaian proses komputatif. Seperti proses mengurang, menambah, mengalikan, dan membagi. Pada dasarnya matematika mengajarkan siswa untuk menjadi individu yang mandiri, berpikir ilmiah dan logis sehingga dapat memecahkan masalah seharihari yang dihadapinya.

Sementara itu menurut Permendikbud RI No. 21 tahun 2016 tentang Standar Nasional Pendidikan pasal 1 No. 14, mata pelajaran matematika bertujuan agar siswa memiliki kemampuan sebagai berikut: (1) Memahami konsep matematika, menjelaskan keterkaitan antarkonsep dan mengaplikasikan konsep atau algoritma, secara luwes, akurat, efisien, dan tepat, dalam pemecahan masalah, (2) Menggunakan penalaran pada pola dan sifat, melakukan manipulasi matematika dalam membuat generalisasi, menyusun bukti, atau menjelaskan gagasan dan pernyataan matematika, (3) Memecahkan masalah yang meliputi kemampuan memahami masalah, merancang model matematika, menyelesaikan model dan menafsirkan solusi yang diperoleh, (4) Mengomunikasikan gagasan dengan simbol, tabel, diagram, atau media lain untuk memperjelas keadaan atau masalah, (5) Memiliki sikap menghargai kegunaan matematika dalam kehidupan, yaitu memiliki rasa ingin tahu, perhatian, danminat dalam mempelajari matematika, serta sikap ulet dan percaya diri dalam pemecahan masalah.

Mengacu pada tujuan ke tiga di atas, pembelajaran matematika di sekolah dasar tidak hanya ditujukan pada peningkatan kemampuan siswa dalam berhitung atau menerapkan rumus atau prosedur dalam menyelesaikan soal-soal rutin saja, tetapi juga pada peningkatan kemampuan siswa dalam pemecahan masalah, baik masalah matematika maupun masalah lain yang menggunakan matematika untuk memecahkannya. Pembelajaran matematika tidak pernah terlepas dengan materi operasi hitung, baik operasi penjumlahan, pengurangan, perkalian maupun pembagian, semua itu salah satunya terkait dengan materi bilangan.

Berkaitan dengan masalah ini, peneliti telah mengadakan observasi pendahuluan di SD YPK Lahairoy Yensawai dengan subjek siswa kelas IV dengan jumlah 20 siswa . Dari kegiatan itu didapatkan bahwa kemampuan pemecahan masalah siswa dalam belajar matematika belum memuaskan. Hal ini terlihat pada hasil Ulangan Harian siswa dengan presentase hanya 56\% siswa yang mendapatkan nilai 50 atau lebih. Sedangkan nilai KKM Matematika di kelas IV adalah 60. Dalam hal ini menunjukkan bahwa ketuntasan siswa dalam belajar belum maksimal, serta kemampuan pemecahan masalah siswa dalam menjawab soal cerita matematika masih di bawah rata-rata.

Guru dituntut untuk dapat memilih model pembelajaran yang dapat memacu siswa untuk terlibat di dalamnya. Banyak model yang dapat digunakan dalam pembelajaran matematika, salah satunya adalah model problem based learning (Pembelajaran Berbasis Masalah). Problem Based Learning atau pembelajaran berbasis masalah adalah suatu model pembelajaran yang menggunakan masalah dunia nyata sebagai suatu konteks bagi peserta didik untuk belajar tentang cara berpikir kritis dan keterampilan pemecahan masalah, serta untuk memperoleh pengetahuan dan konsep yang esensial dari materi kuliah atau materi 
pelajaran (Sudarman, 2007). Berdasarkan uraian di atas, peneliti merasa perlu membahas, meneliti dan menganalisis untuk menjadi bahan penelitian dengan judul, "Pengaruh Problem Based Learning terhadap Kemampuan Memecahkan Masalah Matematika Berbasis Soal Cerita di Kelas IV SD YPK Lahairoy Yensawai ".

Salah satu mata pelajaran yang ada di SD adalah Matematika. Ahmad, (2013) menjelaskan kata matematika berasal dari bahasa latin mathein atau mathema yang berarti belajar hal yang perlu dipelajari. Sedangkan dalam bahasa Belanda matematika disebut wiskunde atau ilmu pasti yang kesemuanya berkaitan dengan penalaran. Adapun Heruman, (2012) menjelaskan "Matematika adalah bahasa symbol : ilmu deduktif: ilmu tentang pola keturunan, dan struktur yang terorganisasi mulai dari unsur yang tidak didefinisikan, ke aksioma atau postulat, dan akhirnya ke dalill”.

Beberapa tokoh juga mengemukakan seperti John Mykelebust dalam Abdurrahman, (2012) yang menyatakan bahwa matematika merupakan bahasa simbolis yang fungsi praktisnya untuk mengekspresikan hubungan-hubungan kuantitatif dan keruangan sedangkan fungsi teoritisnya untuk memudahkan berfikir. Matematika di samping sebagai bahasa simbolis juga merupakan bahasa universal yang memungkinkan manusia memikirkan, mencatat, dan mengkomunikasikan ide mengenai elemen dan kuantitas.

Menurut Susanto, (2015) pemecahan masalah merupakan proses menerapkan pengetahuan (knowldege) yang telah diperoleh siswa sebelumnya kedalam situasi yang baru. Adapun menurut Sani, (2014) pemecahan masalah merupakan proses pengambilan keputusan berdasarkan pengetahuan awal dan menalar. Pemecahan masalah merupakan proses mencari solusi dengan penalaran menggunakan pengetahuan yang telah dimiliki untuk menyelesaikan persoalan yang dihadapi.

Problem based learning merupakan salah satu model pembelajaran yang digunakan di SD. Menurut Fathurrohman, (2015) problem based learning adalah suatu model pembelajaran yang melibatkan peserta didik untuk memecahkan suatu masalah melalui tahap-tahap metode ilmiah sehingga peserta didik dapat mempelajari pengetahuan yang berhubungan dengan masalah tersebut sekaligus memiliki keterampilan untuk memecahkan masalah dan meningkatkan hasil belajar siswa.

Menurut Sani, (2013) model pembelajaran problem based learning merupakan model pembelajaran yang penyampaiannya dilakukan dengan cara menyajikan suatu permasalahan, mengajukan pertanyaan-pertanyaan, memfasilitasi penyelidikan dan membuka dialog. Permasalahan yang dikaji hendaknya merupakan permasalahan kontekstual yang ditemukan oleh siswa dalam kehidupan sehari-hari. Sedangkan Wisudawati, (2014) mendefinisikan PBL sebagai model yang menyajikan suatu masalah yang sesuai kenyataan dan bermakna kepada peserta didik untuk diselidiki secara terbuka dan ditemukan solusi penyelesaiannya.

\section{METODE PENELITIAN}

Jenis penelitian ini adalah penelitian kuantitatif dengan menggunakan metode eksperimen. Hal ini dilakukan dengan membandingkan kelompok yang akan diberi perlakuan yaitu penerapan model pembelajaran problem based learning dengan kelompok pembanding yang tidak menerima penerapan problem based learning. Berdasarkan metode eksperimen yang 
digunakan dalam penelitian ini, maka desain penelitian yang digunakan adalah PretestPosttest Only Design. Variabel bebas disini adalah penggunaan problem based learning sedangkan variable terikatnya adalah kemampuan memecahkan masalah matematika. Dalam penelitian ini populasinya adalah seluruh siswa kelas IV SD YPK Lahairoy Yensawai berjumlah 17 siswa. Sampel penelitian ini menggunakan random sampling, yaitu diundi 9 siswa untuk kelas eksprimen dan 8 siswa untuk kelas kontrol. Adapun teknik pengumpulan data penelitian ini adalah tes (pretest dan posttest).

validitas instrument menggunakan uji validitas ahli (Expert Judgement) yang melibatkan 1 dosen matematika dan 1 guru kelas. Sedangkan pada tahap reliabelitas instrument menggunakan program aplikasi statistic software SPSS.

Uji normalitas bertujuan untuk menguji apakah dalam model regresi, variabel pengganggu atau residual memiliki distribusi normal. Uji normalitas dapat dilakukan dengan uji statistik Kolmogorov Smirnov dengan bantuan software statistic SPSS.

Pengujian homogenitas varians adalah suatu teknik analisis untuk menguji apakah data berasal dari populasi yang homogen atau tidak. Untuk menguji homogenitas varians terhadap dua kelompok sampel dapat dilakukan dengan uji $\mathrm{F}$ dengan taraf signifikasi $\alpha=0,05$ dengan bantuan software statistic SPSS.

Untuk menguji hipotesis (apakah hipotesis diterima atau ditolak) maka dilakukan analisa secara kuantitatif. Pengujian hipotesis secara kuantitatif ini menggunakan uji-t dengan taraf signifikasi $\alpha$ $=0,05$ dengan bantuan software statistic SPSS.

\section{HASIL DAN PEMBAHASAN}

Penelitian ini menggunakan pengujian validitas ahli atau expert judgment, dimana peneliti melibatkan 1 (satu) dosen validator matematika dan 1 guru kelas. Yang mana menyatakan bahwa instrument yang telah dibuat layak digunakan.

Untuk menguji reliabilitas instrument peneliti memakai bantuan program aplikasi software statistic SPSS. Berikut ini hasil uji reliabilitasnya:

\begin{tabular}{rr}
\multicolumn{2}{c}{ Reliability Statistics } \\
\hline Cronbach's Alpha & N of Items \\
\hline .876 & 10
\end{tabular}

Untuk menguji hasil data prestest digunakan program aplikasi software statistic SPSS. Berikut ini hasil pretest kelas control. Untuk menguji hasil data prestest digunakan program aplikasi software statistic SPSS. Berikut ini hasil posttest kelas kontrol:

Pada penelitian ini peneliti menggunakan pengujian validitas data menggunakan aplikasi statistik SPSS V16. Adapun hasil pengujian data pretest dan posttest tersebut adalah sebagai berikut:

Tabel 1. Hasil data pretest dan postest

Item-Total Statistics

\begin{tabular}{lrrrr}
\hline & $\begin{array}{c}\text { Scale } \\
\text { Mean if } \\
\text { Item } \\
\text { Deleted }\end{array}$ & $\begin{array}{c}\text { Scale } \\
\text { Variance if } \\
\text { Item }\end{array}$ & $\begin{array}{c}\text { Corrected } \\
\text { Item-Total } \\
\text { Correlatio } \\
\text { nele }\end{array}$ & $\begin{array}{c}\text { Cronbach's } \\
\text { Alpha if } \\
\text { Item } \\
\text { Deleted }\end{array}$ \\
\hline Soal_1 & 51.35 & 257.118 & .749 & .943 \\
Soal_2 & 51.71 & 239.471 & .649 & .942 \\
Soal_3 & 52.59 & 248.507 & .543 & .946 \\
Soal_4 & 53.18 & 237.029 & .604 & .944 \\
Soal_5 & 51.94 & 209.059 & .901 & .930 \\
Soal_6 & 51.41 & 219.132 & .888 & .931 \\
Soal_7 & 51.06 & 236.559 & .733 & .938 \\
Soal_8 & 51.53 & 217.515 & .900 & .930 \\
Soal_9 & 51.59 & 217.132 & .928 & .929 \\
Soal_1 & 51.94 & 197.934 & .909 & .931 \\
0 & & & & \\
\hline
\end{tabular}

Dari tabel 1 diatas dapat dilihat bahwa nilai pada kotak Corrected Item Total Correlation adalah diatas dari nilai rtabel 
yaitu 0,412. Jadi, data tersebut dapat dikatakan valid karena rhitung > rtabel.

Uji reliabelitas dilakukan terhadap item pertanyaan yang dinyatakan valid. suatu variabel dikatakan reliabel jika jawaban terhadap pertanyaan selalu konsisten. Selanjutnya dihitung reabilitasnya menggunakan rumus Alpha Croanbach's. Perhitungan dilakukan dengan dibantu oleh program SPSS V16. Adapun hasil uji reabilitas soal pretest dan postest kemampuan memecahkan masalah matematika berbasis soal cerita yang diujikan maka hasil analisis reabilitasnya adalah diatas 0,6 yaitu 0,500 atau $50 \%$ untuk nilai pretest dan nilai postestnya adalah 0,957 atau $95,7 \%$.

Uji Normalitas digunakan untuk mengukur apakah data tersebut memiliki distribusi normal atau tidak. dalam hal ini uji normalitas data dilakukan dengan menggunakan uji Kolmogrov-Smirnov. Adapun hasil uji Kolmogrov-Smirnov dengan memakai SPSS V.16 sebagai berikut:

\begin{tabular}{|c|c|c|c|}
\hline \multirow[b]{2}{*}{$\mathrm{N}$} & & $\begin{array}{c}\text { Pretest } \\
\text { Eksperim } \\
\text { en }\end{array}$ & $\begin{array}{c}\text { Postest } \\
\text { Ekpserim } \\
\text { en }\end{array}$ \\
\hline & & 9 & 9 \\
\hline \multirow{2}{*}{$\begin{array}{l}\text { Normal } \\
\text { Parameters }^{\mathrm{a}}\end{array}$} & Mean & 59.889 & 87.500 \\
\hline & Std. Deviation & 7.6066 & 21.6506 \\
\hline \multirow{3}{*}{$\begin{array}{l}\text { Most Extreme } \\
\text { Differences }\end{array}$} & Absolute & .284 & .385 \\
\hline & Positive & .161 & .282 \\
\hline & Negative & -.284 & -.385 \\
\hline \multicolumn{2}{|c|}{ Kolmogorov-Smirnov Z } & .851 & 1.154 \\
\hline \multicolumn{2}{|c|}{ Asymp. Sig. (2-tailed) } & .464 & .139 \\
\hline
\end{tabular}

Hasil uji normalitas data tabel 2 di atas dengan taraf signikasi $\alpha=0,05$ dengan pengambilan keputusan jika nilai signifikasi $\leq 0,05$ maka distribusi data adalah tidak normal, dan jika nilai signifikasi $\geq 0,05$ maka distribusi data adalah normal. Berdasarkan Tabel 2 dapat disimpulkan bahwa data variabel berdistribusi normal karena nilai Asymp. Sig. (2-tailed) untuk pretest 0,464 dan postest 0,139 lebih besar dari 0,05.

Uji hipotesis digunakan untuk menguji apakah hipotesis diterima atau ditolak, maka dilakukan analisa secara kuantitatif dengan menggunakan uji-t dengan taraf signifikasi $\alpha=0,05$.

Tabel 3. hasil uji t

Paired Samples Statistics

\begin{tabular}{lllll}
\hline & & & $\begin{array}{l}\text { Std. } \\
\text { Deviation }\end{array}$ & $\begin{array}{l}\text { Std. Error } \\
\text { Mean }\end{array}$ \\
\hline $\begin{array}{l}\text { Pair } \\
1\end{array}$ & $\begin{array}{l}\text { Pretest } \\
\text { Eksperimen }\end{array}$ & 59.8899 & 7.6066 & 2.5355 \\
& $\begin{array}{l}\text { Postest } \\
\text { Ekpserimen }\end{array}$ & 87.5009 & 21.6506 & 7.2169 \\
\hline
\end{tabular}

Pada tabel 3 di atas diperlihatkan hasil ringkasan statistik deskriptif dari kedua data. Mean merupakan nilai rata-rata dari suatu data, untuk pretest adalah 59,889 dan postest adalah 87,500. $\mathrm{N}$ merupakan jumlah sampel yang mengikuti kelas eksperimen sebanyak 9 sampel. Std. Deviation pada pretest adalah 7,6066 dan postest adalah 21,6506. Std Error Mean pada pretest adalah 2,5355 dan postest adalah 7,2169.

Diketahui bahwa hasil uji t diperoleh thitung 4233 dan ttabel pada signifikasi 0,05 sebesar 1,74 ( $\mathrm{t}_{\text {hitung }}<\mathrm{t}_{\text {tabel }}$ ), maka dapat disimpulkan bahwa $\mathrm{Ha}$ diterima dan $\mathrm{H}_{0}$ ditolak yang berarti hipotesis penelitian terjawab karena dapat hasil yang signifikan terhadap kemampuan memecahkan masalah matematika siswa sesudah mengajar menggunakan pembelajaran Problem Based Learning.

Berdasarkan hasil penelitian pada siswa kelas IV SD YPK Lahairoy Yensawai dengan memberikan perlakuan menggunakan model pembelajaran Problem Based Learning dalam proses pembelajaran matematika, peneliti mendapatkan hasil uji 
normalitas data dengan Kolmogrov-Smirnov bahwa data variabel berdistribusi normal karena nilai Asymp. Sig. (2-tailed) pada pretest 0,464 dan postest $0,139 \geq 0,05$. Uji t dilakukan dengan Paired Sampel Test bahwa terdapat masing-masing variabel bebas terhadap variabel terikat dan untuk hasil uji hipotesis diperoleh diperoleh thitung 4233 dan ttabel pada signifikasi 0,05 sebesar 1,74 ( $\left.\mathrm{t}_{\text {hitung }}<\mathrm{t}_{\text {tabel }}\right)$, maka uji hipotesis teruji kebenarannya bahwa terdapat pengaruh problem based learning terhadap kemampuan memecahkan masalah matematika siswa berbasis soal cerita. Model pembelajaran problem based learning dalam proses pembelajaran matematika membuat siswa lebih aktif dengan melibatkan seluruh kemampuan siswa untuk mendapatkan nilai matematika yang bagus.

Hasil penelitian ini sesuai dengan hasil penelitian dari Juanda Rahmah, (2017) yang berjudul " Pengaruh Problem Based Learning Terhadap Hasil Belajar Matematika Siswa Kelas IV SDN Gugus Wijaya Kusuma Ngaliyan Semarang" yang menyatakan bahwa model pembelajaran Problem Based Learning berpengaruh terhadap Hasil belajar matematika siswa. Berdasarkan Uraian diatas dapat disimpulkan bahwa Penggunaan Problem Based Learning pada proses pembelajaran dapat memberikan pengaruh terhadap kemampuan memecahkan masalah matematika siswa kelas IV SD YPK Lahairoy Yensawai, Raja Ampat

\section{KESIMPULAN}

Berdasarkan hasil analisis data yang terkumpul serta pengolahan analisis dengan menggunakan aplikasi SPSS 16 menunjukkan bahwa:

Data hasil distribusi frekuensi pada Pretest dan Postest kelompok Eksperimen menunjukkan perbedaan yang signifikan karena untuk Pretest siswa lebih banyak mendapatkan nilai 60-69 dengan presentase $66,7 \%$ sedangkan untuk Postest siswa mampu mendapatkan nilai 90-100 dengan $66,7 \%$.

Peneliti menggunakan pengujian validitas ahli atau expert judgment dimana peneliti melibatkan 1 dosen validator matematika dan 1 Guru Kelas. Validasi diisi oleh ahli untuk mengambil keputusan dengan mengirimkan panduan lembar validasi kepada validator. Hasil dari lembar validasi dijadikan masukan dalam memperbaiki dan mengembangkan instrumen. (Surat keterangan Validasi Terlampir).

Uji Reliabelitas dikatakan reliabel apabila hasil Alpha Croanbach's diatas 0,6. Berdasarkan hasil uji reabilitas soal pretest dan postest kemampuan memecahkan masalah matematika berbasis soal cerita yang diujikan maka hasil analisis reabilitasnya adalah diatas 0,6 yaitu 0,500 atau $50 \%$ untuk nilai pretest dan nilai postestnya adalah 0,957 atau $95 \%$.

Uji t dilakukan dengan Paired Sampel Test bahwa terdapat masing-masing variabel bebas terhadap variabel terikat dan untuk hasil uji hipotesis diperoleh thitung 4233 dan ttabel pada signifikasi 0,05 sebesar 1,74 (thitung < ttabel), maka uji hipotesis teruji kebenarannya bahwa terdapat pengaruh problem based learning terhadap kemampuan memecahkan masalah matematika siswa berbasis soal cerita.

\section{DAFTAR RUJUKAN}

Faturrohman, M. (2015). Model-model Pembelajaran Inovatif. Yogyakarta: Ar-Ruzz Media.

Fatimah, S., \& Sujati. (2011). Meningkatkan Kemampuan Menyelesaikan Soal Cerita Matematika Melalui Metode Bermain Peran di Kelas II SDN Waitugas I Ngawen Gunung Kidul. Jurnal Didaktika Universitas Negeri 
Yogyakarta Vol 4 No 1.

Gunantara. (2016). Penerapan Model

Pembelajaran Problem Based Learning

Untuk Meningkatkan Kemampuan

Pemecahan Masalah Matematika Siswa

Kelas V . Singaraja, Universitas Pendidikan Ganesha.

Gagne, R., \& Wager, W. (1992). Principles of Instructional Design(4nd ed). Orlando: Holt, Rinehart and Winstone, Inc.

Heruman. (2012). Model Pembelajaran Matematika di Sekolah Dasar. Bandung: PT. Remaja Rosdakarya.

Kurniasih, I., \& Sani, B. (2016). Ragam Pengembangan Model Pembelajaran Untuk Peningkatan Profesionalitas Guru. Yogyakarta: Kata Pena.

Mulyono, Abdurrahman. (2012). Pendidikan Bagi Anak Kesulitan Belajar. Jakarta: Rineka Cipta.

Permendikbud RI No. 21. (2016). Tentang Standar Nasional Pendidikan.

Rahardjo, M., \& Waluyati, A. (2011). Pembelajaran Soal Cerita Operasi Hitung Pecahan di Sekolah Dasar. Yogyakarta: PPPTK Matematika

Rahmah, J. (2017). Pengaruh Model Problem Based Learning Terhadap Hasil Belajar
Matematika Siswa Kelas IV SDN Gugus Wijaya Kusuma Ngaliyan. Semarang : Universitas Negeri Semarang.

Ruchaedi, D., \& Basuki, I. (2016). Pengaruh Problem Based Learning Terhadap Kemampuan Heuristik Pemecahan Masalah dan Sikap Matematis Siswa Sekolah Dasar. Jurnal Cakrawala Penjas Vol.2 No. 2.

Runtukahu, T., \& Selpius, K. (2016). Pembelajaran Matematika Dasar Bagi Anak Berkesulitan Belajar. Yogyakarta: Ar-Ruzz Media.

Sani, R. A. (2013). Pembelajaran Saintifik untuk Implementasi Kurikulum. Jakarta: Bumi Aksara.

Sudarman. (2007). Problem Based Learning : Suatu Model Pembelajaran Untuk Mengembangkan Dan Meningkatkan Kemampuan Memecahkan Masalah. Jurnal Pendidikan Inovatif.

Susanto, Ahmad. (2015). Teori Belajar dan Pembelajaran di Sekolah Dasar. Jakarta: Prenamedia Group.

Wisudawati, W., \& Sulistyowati, E. (2015). Metodologi Pembelajaran IPA. Jakarta: Bumi

Aksara. 